\title{
Synthesis of Some New Selenonitrone Compounds
}

\author{
BATOOL SALEH HADDAD \\ Department of Chemistry, College of Science, University of Basrah, Basrah, Iraq. \\ Corresponding author E-mail: batoolsalih16@yahoo.com \\ http://dx.doi.org/10.13005/ojc/330615
}

(Received: July 11, 2017; Accepted: August 02, 2017)

\begin{abstract}
The carbonyl selenonitrile and dicarbonyl diselane compounds were prepared by using the inorganic reagent such as potassium selenocyanate. New nitrone compounds were synthesized from the condensation of carbonyl group in the selenocarbonyl compounds with substituted N-phenylhydroxylamine and N-benzyl hydroxylamine. The resulting products were identified by physical properties such as melting point (M.p.), retardation factor (Rf) and color. Also compounds showed the expected data in identification techniques such as FTIR, 1H NMR, $13 \mathrm{C}$ NMR, mass spectroscopy and Elemental analysis (CHN). The results proved the validity of the expected chemical structures of synthesized compounds.
\end{abstract}

Keywords: Nitrones, Potassium selenonitryl, Carbonyl selenonitrile,

\section{INTRODUCTION}

Interest in nitrone is due to their successful application, can be used as building blocks in the synthesis of various natural and biologically active compounds. Nitrone has been extensively investigated, because of their utility as versatile synthetic intermediates. Interest in nitrone also due to their successful application, can be used as building blocks in the synthesis of various natural and biologically active compounds. The synthesis of nitrone containing sulfur and nitrogen have been extensively studied ${ }^{1,2}$, while the synthesis of nitrone containing selenonitrile and diselenide analogues have not been appreciably investigated ${ }^{3,4}$. This is mainly due to the easily decomposed of nitrone and organoselenium compounds in light and moisture. In this research ${ }^{5,6}$, several new carbonyl compounds containing selenonitrile group and diselenide $^{7}$ group were prepared. Diphenyl diselenide [(PhSe $) 2]$ is being carried out by the alkaline hydrolysis of substiuted phenylselenonitrile (the synthesis of phenylselenonitrile) is being carried out by the reaction between potassium cyanide and selenium metal ${ }^{8}$. For the preparation of nitrones, the most popular method is the condensation of aldehydes or ketones with $\mathrm{N}$ monosubstituted hydroxylamines ${ }^{9,10,11}$. Recently, organ-oselenium compound has gradually investigated because of their interesting reactivates and their pharmaceutical applications ${ }_{12,13}$. The nitrone compounds are of marked interest because of their anti-tumor ${ }^{14,15}$, antibacterial ${ }^{16}$ and of anticancer agents by intercalating DNA ${ }^{17,18,19}$ with higher affinity and found it was easily metabolized with low toxicity ${ }^{20}$. The aim of the study : according 
to the literature, study has been done on nitrone compounds and organoselenium compounds separately. These two classes of compounds have been combined in this study.

\section{MATERIALS AND METHODS}

FT.IR spectra were measured by an instrument called BRUKER and the range was between $375-4500 \mathrm{~cm}^{-1} .{ }^{1} \mathrm{H}$ NMR spectra were measured by an instrument called BRUKER 300 $\mathrm{MHz}$. The samples were recorded in DMSO solutions containing TMS as internal standard. Chemical shifts for all ${ }^{1} \mathrm{H}$ and ${ }^{13} \mathrm{C}$ NMR spectra were reported in ä units downfield from internal reference Me4Si. Elemental analyses (C, $\mathrm{H}$ and $\mathrm{N}$ ) were obtained and Mass spectra were measured by instruments called MP- H- Vario Elemental analyzer and Agilent- O.T-LABRO, respectively.

All the carbonyl selenonitrile compounds being carried out by the reaction of the corresponding benzoyl chloride with potassium selenocyanate. Nitrone compounds were prepared from the condensation of carbonyl selenonitrile with $\mathrm{N}$-phenyl hydroxylamine and $\mathrm{N}$-benzyl hydroxyl amine compounds.

The general procedure of preparation carbonyl selenonitrile ${ }^{21,22}$ : To a stirred Solution of (0.8) KCN in absolute ethanol (50 ml), (1 g.; 125 mole) of selenium metal was added. The reaction was in red color. After $3 \mathrm{~h}$. of reflux, $(206 \mathrm{ml} 0.025$ mole) of substituted benzoyl chloride was added and refluxed for $2 \mathrm{~h}$. The reaction was followed by TLC. The result was filtered, washed, dried and recrystallized from absolute ethanol.

The general procedure of preparation diorgano diselenide ${ }^{23}$ : To a stirred solution of $(0.28$ $\mathrm{gm} ; 1.02 \mathrm{~mole}$ ) in $25 \mathrm{ml}$ absolute ethanol of carbonyl selenonytrile, a solution of $(0.16 \mathrm{~g}, 2.47$ mole $)$ in $15 \mathrm{ml}$ absolute ethanol sodium hydroxide was added. The mixture was stirred for $50 \mathrm{~min}$. at $40^{\circ} \mathrm{C}$. After one $\mathrm{h}$ of reflux, the reaction was followed by TLC, the mixture reaction cooled to $\mathrm{R}$.T. and filtered. The filtrate was acidified with $10 \% \mathrm{HCL}$. A red solid compound was obtained, washed with a small amount of benzene and dried. Recrystalization from a mixture of methanol and dichloro methane (1:4), gave a red solid compounds.

The General Procedure of synthesis nitrone ${ }^{24-26:}$ In a $250 \mathrm{ml}$ one-necked round bottomed flask (0.02 mole) of selenocarbonyl compounds were placed and a solution of $15 \mathrm{gm}$ of anhydrous $\mathrm{CaCl}_{2}$ with added $30 \mathrm{ml}$ of absolute ethanol was added. The solution was stirred and warmed to $50{ }^{\circ} \mathrm{C}$ and a solution of $(0.02 \mathrm{~mol})$ of $[(\mathrm{N}$-phenyl hydroxylamine) in $30 \mathrm{ml}$ of absolute ethanol was added, to synthesis the compounds $\left(\mathrm{N}_{1}, \mathrm{~N}_{2}, \mathrm{~N}_{3}\right.$ and $N_{4}$ ) while the compound $N_{5}$ was synthesized by added N-benzyl hydroxylamine ${ }^{25}$. 3 drops of benzene sulfunic acid was added to the mixture. After the addition was completed the reaction mixture was kept with stirring in dark, overnight at room temperature. The reaction was followed by TLC, the mixture was cooled and then the

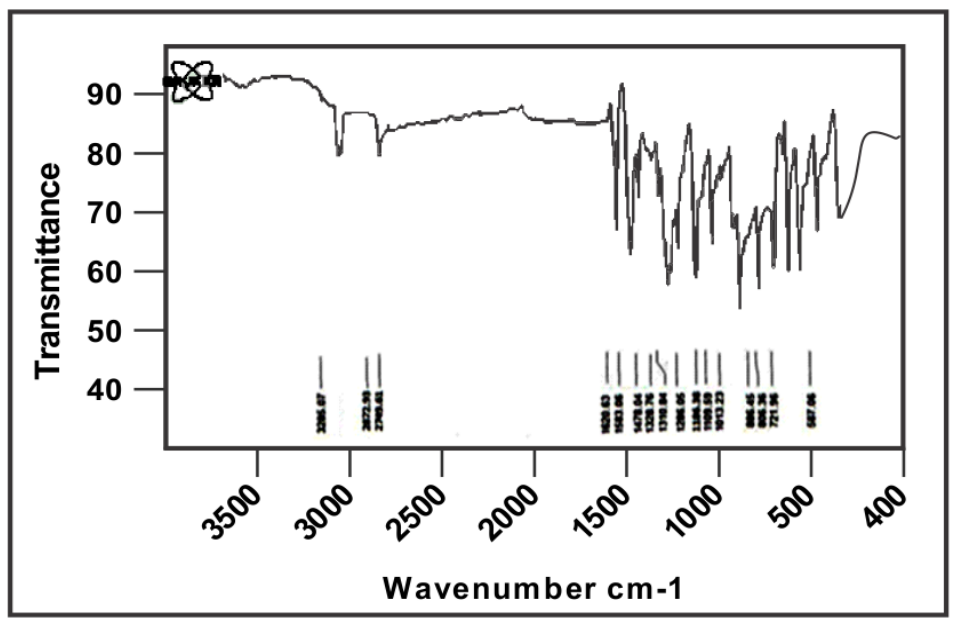

Fig.1. IR spectrum of compound $\left(\mathrm{N}_{4}\right)$ 


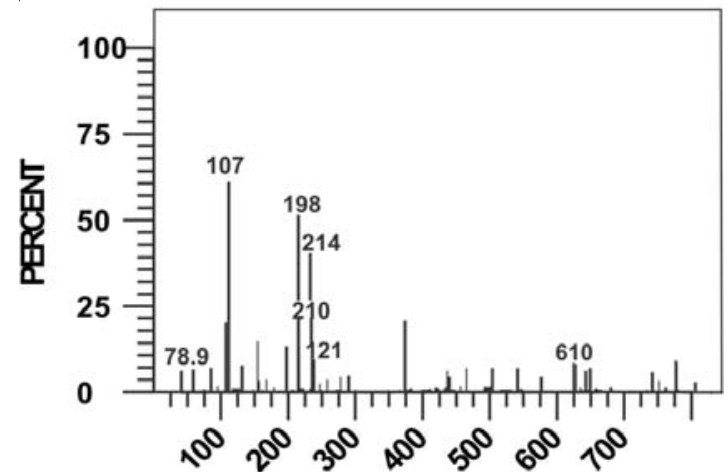

Fig.2. Mass spectrum of compound $\left(\mathrm{N}_{4}\right)$

precipitated was filtered by suction filtration and the product was recrystallized by abs. ethanol. All the synthesized compounds were characterized by FTIR, 1H NMR, 13C NMR, mass spectroscopy and Elemental analysis $(\mathrm{CHN})$ and all the results were in agreement with the theoretical calculation. For example the spectra are represented in the figures $(1-4)$ for compound $\left(\mathrm{N}_{4}\right)$. Chemical structure and some physical properties of nitrones are represented in Table (1).

The carbonyl selenonitril compounds was prepared by the reaction of potassium cyanide with benzoylchloride as explain in equation (a).

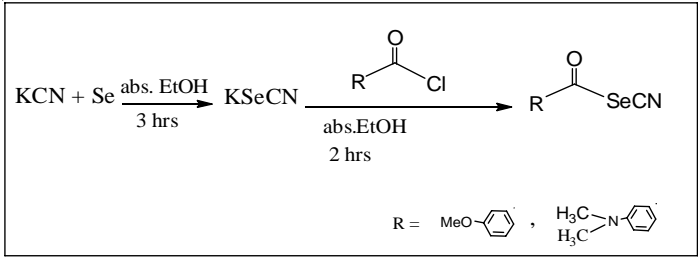

Equation (a)

Dicarbonyl dislenide can be prepared by the alkaline hydrolysis of carbonyl selenonitrile compounds, as explain in equation (b).

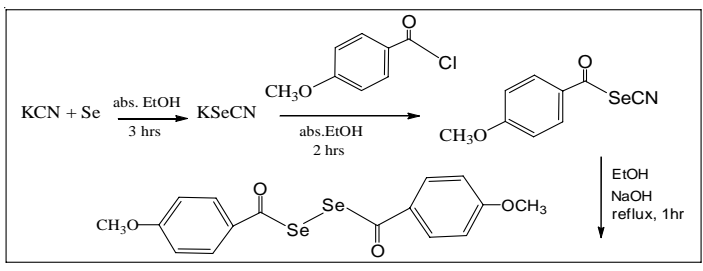

Equation (b)

$\mathrm{N}$-phenylhydroxylamine were synthesized by the reduced of nitro aromatic compounds with zinc dust and using water as a solvent while $\mathrm{N}$ benzylhydroxylamine was prepared by the reaction between hydroxyl amine hydrochloride and benzyl chloride, in the presence of sodium carbonate.

Table. 1: Chemical structure and some physical properties of nitrones

\begin{tabular}{|c|c|c|c|c|c|c|}
\hline Symbols & $\begin{array}{l}\text { Time of } \\
\text { reflux }\end{array}$ & Color & Yield\% & Solution of TLC & $\mathrm{Rf}$ & Structures \\
\hline $\mathrm{N}_{1}$ & 9 & Orange & 55 & $\begin{array}{c}\text { Ethylacetate } \\
\text { hexane } 2.5: 7.5\end{array}$ & 0.54 & \\
\hline $\mathrm{N}_{2}$ & 9 & Yellow & 57 & $\begin{array}{c}\text { Ethylacetate } \\
\text { hexane 6.5:3.5 }\end{array}$ & 0.66 & \\
\hline $\mathrm{N}_{3}$ & 11 & Orange & 70 & $\begin{array}{c}\text { Ethylacetate } \\
\text { hexane 5.0:5.5 }\end{array}$ & 0.61 & \\
\hline $\mathrm{N}_{4}$ & 10 & Yellow & 61 & $\begin{array}{c}\text { Ethylacetate } \\
\text { hexane 7.5:2.5 }\end{array}$ & 0.59 & \\
\hline $\mathrm{N}_{5}$ & 9 & Orange & 69 & $\begin{array}{c}\text { Ethylacetate } \\
\text { hexane 5.0:5.0 }\end{array}$ & 0.66 & \\
\hline
\end{tabular}




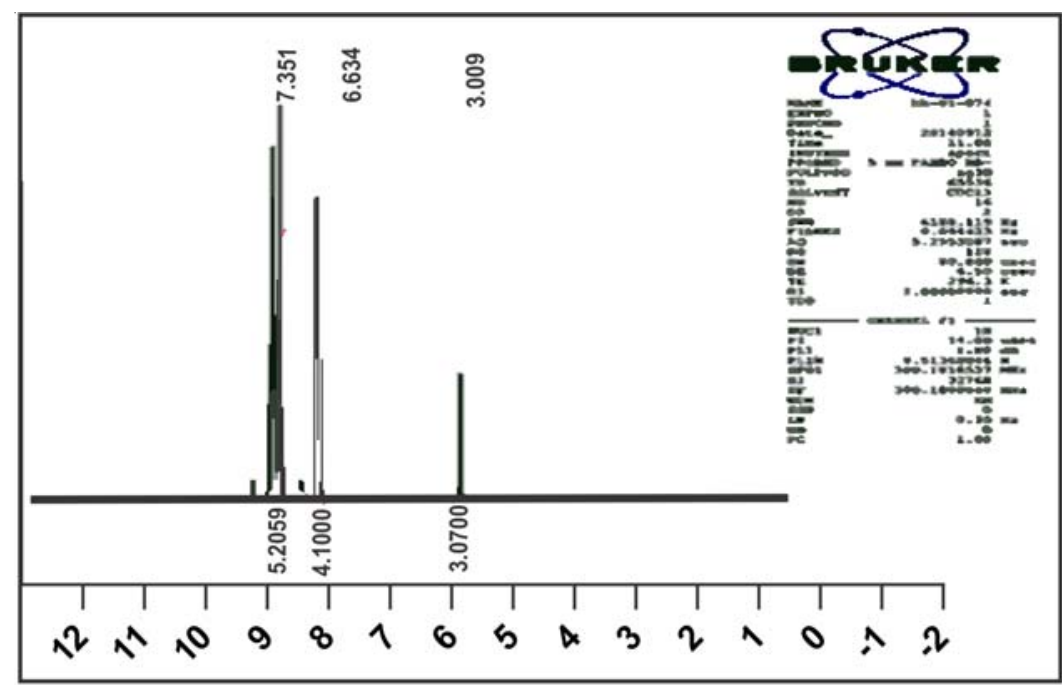

Fig.3. 1H NMR spectrum of compound $\left(\mathrm{N}_{4}\right)$

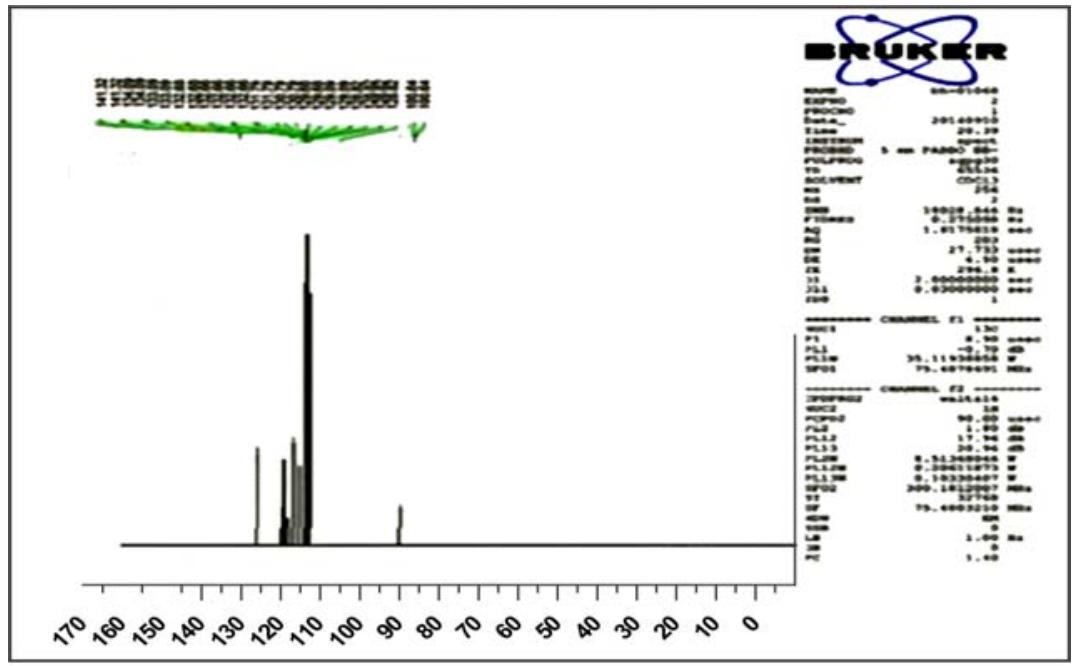

Fig.4. 13C NMR spectrum of compound $\left(\mathrm{N}_{4}\right)$

Nitrones were synthesized by the condensation of substituted caronyl selenonitrile with $\mathrm{N}$-phenylhydroxylamine and $\mathrm{N}$ benzylhydroxylamine as explain in equation (c) and scheme (1).

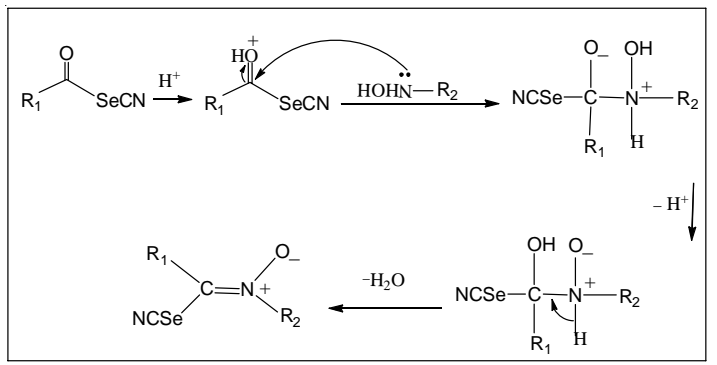

Scheme (1)

The mechanism of synthesis nitrone compounds

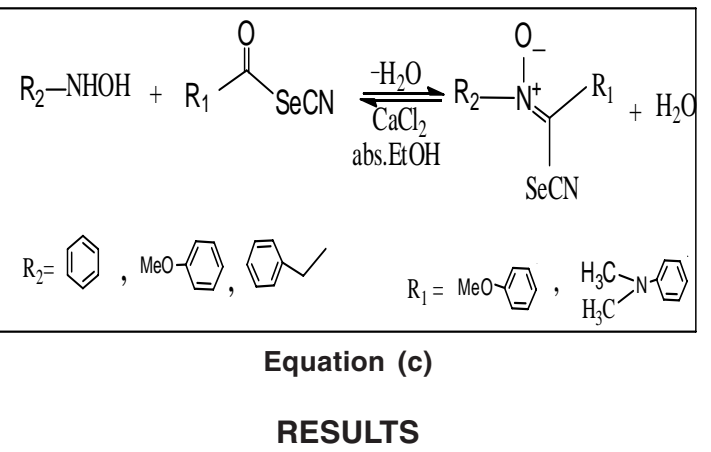

The resulting data were obtained for the synthesized compounds from analysis data as following: 


\section{$\mathrm{N}-(1,1-(4-m e t h o x y p h e n y l)$ selenonitrile methylene) aniline oxide $\left(\mathrm{N}_{1}\right)$}

Yield: 55 \%. M.p. $100-99^{\circ} \mathrm{C}$. FTIR v $/ \mathrm{cm}^{-1}: 1600$ $(\mathrm{C}=\mathrm{N}), 1394(\mathrm{C}=\mathrm{C}), 1377$ (C-N), 588 (C-Se), 2101 $(\mathrm{C} \equiv \mathrm{N}), 1199$ (N-O), 2988 (C-H aliph), 3099 (C-H arom.). ${ }^{1} \mathrm{H}$ NMR [300MHz, (DMSO), $\delta$ (ppm)]; 6.6 (4H-ph), m 7.9 (5H-ph), $3.6\left(\mathrm{CH}_{3}\right) .{ }^{13} \mathrm{C}$ NMR [300MHz, (DMSO), $\delta(\mathrm{ppm})] ; 50.6\left(\mathrm{CH}_{3}\right), 123.4$, 123.6, 129.0, 129.7, 129.9, 149.0 (ph-N), 130.5, 130.6, 130.8,131, 13l.7, 160.4 (ph-O), $165(\mathrm{C}=\mathrm{N})$, 110 (CN). For $\mathrm{C}_{15} \mathrm{H}_{12} \mathrm{~N}_{2}$ OSe. (Found) $54.11 \% \mathrm{C}$, $3.50 \% \mathrm{H}$ and $8.55 \% \mathrm{~N}$. MS: m/z: $330.9\left(\mathrm{M}^{+}\right)$.

\section{$\mathrm{N}$-(1, 1-(N, N-dimethylamino phenyl) selenonitrile methylene) aniline oxide $\left(\mathrm{N}_{2}\right)$}

Yield: 57 \%. M.p. $80-82^{\circ} \mathrm{C}$. FTIR v $/ \mathrm{cm}^{-1}: 1605$ $(\mathrm{C}=\mathrm{N}), 1390(\mathrm{C}=\mathrm{C}), 1380(\mathrm{C}-\mathrm{N}), 589(\mathrm{C}-\mathrm{Se}), 2110$ (CN), 1188 (N-O), 2998 (C-H aliph), 3100 (C-H arom.). ${ }^{1} \mathrm{H}$ NMR [300MHz, (DMSO), $\delta$ (ppm)]; 6.4 (4H-ph), m 7.7 (5H-ph), $2.9\left(\mathrm{CH}_{3}\right) .{ }^{13} \mathrm{C} \mathrm{NMR}$ [300MHz, (DMSO), $\delta$ (ppm)]; 50.6, $50.9\left(\mathrm{CH}_{3}-\mathrm{N}\right)$, 121.4, 121.6, 122.9, 123.3, 126.9, 147.0 (ph-N), 129.5, 129.9, 130.4, 130.5, 13I.8, 161.0 (ph-O), 162 $(\mathrm{C}=\mathrm{N}), 115(\mathrm{CN})$. For $\mathrm{C}_{16} \mathrm{H}_{15} \mathrm{~N}_{3}$ OSe. (Found) 55.30 $\% \mathrm{C}, 4.30 \% \mathrm{H}$ and $12.30 \% \mathrm{~N}$. MS: $\mathrm{m} / \mathrm{z}$ : 344( $\left.\mathrm{M}^{+}\right)$.

\section{$\mathrm{N}-(1,1-(\mathrm{N}, \mathrm{N}$-dimethylamino phenyl) selenonitrile} methylene)-4-methoxy aniline oxide $\left(\mathbf{N}_{3}\right)$.

Yield: 70 \%. M.p. $83-82^{\circ} \mathrm{C}$. FTIR v $/ \mathrm{cm}^{-1}: 1590$ $(\mathrm{C}=\mathrm{N}), 1375(\mathrm{C}=\mathrm{C}), 1385(\mathrm{C}-\mathrm{N}), 590$ (C-Se), 2111 (CN), 1180 (N-O), 2988(C-H aliph), 3110 (C-H arom.). ${ }^{1} \mathrm{H}$ NMR [300MHz, (DMSO), $\delta$ (ppm)]; 6.7 (4H-ph-O), $7.9(4 \mathrm{H}-\mathrm{ph}-\mathrm{N}), 3.9\left(\mathrm{CH}_{3}-\mathrm{N}\right), 2.7\left(\mathrm{CH}_{3}-\right.$ O). ${ }^{13} \mathrm{C}$ NMR [300MHz, (DMSO), $\delta$ (ppm)]; 49.8, 50.1 $\left(\mathrm{CH}_{3}-\mathrm{N}\right), 50.4\left(\mathrm{CH}_{3}-\mathrm{O}\right), 122.6,122.8,122.9,124.3$, 124.6, 166.9 (ph-O), 127.1, 127.9, 131.4, 131.1, 133.7, 147.7 (ph-N), $162.5(\mathrm{C}=\mathrm{N}), 113(\mathrm{CN})$. For $\mathrm{C}_{17} \mathrm{H}_{17} \mathrm{~N}_{3} \mathrm{O}_{2} \mathrm{Se}$. (Found) $54.57 \% \mathrm{C}, 4.90 \% \mathrm{H}$ and $11.22 \%$ N. MS: m/z: 373.9( $\left.\mathrm{M}^{+}\right)$.

\section{N, N'-(diselanediyl bis (4-methoxyphenyl} methan-1-yl-1-ylidene)) bis (aniline oxide). $\left(\mathrm{N}_{4}\right)$

Yield: $61 \%$. M.p. $90-92^{\circ} \mathrm{C}$. FTIR v $/ \mathrm{cm}^{-1}: 1620$ $(\mathrm{C}=\mathrm{N}), 13710(\mathrm{C}=\mathrm{C}), 1328(\mathrm{C}-\mathrm{N}), 587(\mathrm{C}-\mathrm{Se}), 1186$ (N-O), 2872 (C-H aliph), 31285 (C-H arom.) ${ }^{1} \mathrm{H}$ NMR [300MHz, (DMSO), $\delta$ (ppm)]; $3.0\left(\mathrm{CH}_{3}\right), 7.3$ (ph-N) 6.6 (ph-O). ${ }^{13} \mathrm{C}$ NMR [300MHz, (DMSO), $\delta$ (ppm)]; 161.0, $160.5(\mathrm{C}=\mathrm{N}), 30.3,31.2\left(\mathrm{CH}_{3}\right), 121.8$, $121.9,122.3,122.9,123.3,123.9,123.6,124.5$, 124.6, 124.7.166.3, 166.9 (ph-O), 124.8, 124.6, $124.9,125.4,125.9,127.3,127.9,128.6,129.0$, 129.2, 147.0, 146.5 (ph-N), For $\mathrm{C}_{28} \mathrm{H}_{24} \mathrm{~N}_{2} \mathrm{O}_{4} \mathrm{Se}_{2}$. (Found) $55.30 \%$ C, $3.86 \% \mathrm{H}$ and $4.44 \%$ N. MS: m/ z: $610\left(\mathrm{M}^{+}\right)$
N, N'-(diselanediyl bis ((4-methoxyphenyl) methan-1-yl-1-ylidene)) bis(1-(3-methoxy phenyl) methanamine oxide) $\left(\mathrm{N}_{5}\right)$

Yield: $69 \%$. M.p. $90-92^{\circ} \mathrm{C}$. FTIR v $/ \mathrm{cm}^{-1}: 1589$ $(\mathrm{C}=\mathrm{N}), 1378(\mathrm{C}=\mathrm{C}), 1378(\mathrm{C}-\mathrm{N}), 581$ (C-Se), 2976 1187 (N-O), (C-H aliph), 3108 (C-H arom.). ${ }^{1} \mathrm{H}$ NMR [300MHz, (DMSO), $\delta$ (ppm)]; $1.7\left(\mathrm{CH}_{3}\right), 7.6$ (ph-N) 7.3 (ph-O). ${ }^{13} \mathrm{C}$ NMR [300MHz, (DMSO), $\delta$ (ppm)]; 161.0, $161.5(\mathrm{C}=\mathrm{N}), 34.9,35.1,35.4,35.9\left(\mathrm{CH}_{3}\right)$, 60.4, $60.7\left(\mathrm{CH}_{2}\right) 121.5,122.4,122.9,123.9,124.3$, $124.9,125.6,125.5,127.6,128.7,162.5,163.9$ (phO), 1298, 130.6, 130.9, 131.4, 1329, 133.3, 133.9, $134.0,134.6,134.8,135.0,146.5$ (ph-N), For $\mathrm{C}_{32} \mathrm{H}_{28} \mathrm{~N}_{2} \mathrm{O}_{6} \mathrm{Se}_{2}$. (Found) $55.38 \% \mathrm{C}, 4.20 \% \mathrm{H}$ and $4.12 \%$ N. MS: m/z: $693.8\left(\mathrm{M}^{+}\right)$.

\section{DISCUSSION}

Five new nitrone compounds were synthesized by using the condensation method between carbonyl group (carbonyl selenonitryl and dicarbonyl diselenide) and $\mathrm{N}$-(phenyl and benzyl)hydroxylamine group. Various substituted carbonyl selenonitrile compounds were synthesized by the reaction of potassium selenocyanate as inorganic reagent with benzoyl chloride. This method was easier than other methods to synthesis organoselenium compounds. The chemical structures of new selenonitrone compounds were characterized by identification methods.

All IR spectra of nitrone compounds showed the disappearance of $(\mathrm{C}=\mathrm{O})$ of carbonyl selenonitrile band in the region $(1700) \mathrm{cm}^{-1}$ and the appearance of $(\mathrm{C}=\mathrm{N}),(\mathrm{N}-\mathrm{O})$ and $(\mathrm{C}-\mathrm{N})$ bands in the regions (1589-1607) $\mathrm{cm}^{-1},(1180-1199) \mathrm{cm}^{-1}$ and (1377-1388) $\mathrm{cm}^{-1}$ respectively. The IR spectra of compounds $\left(\mathrm{N}_{4}, \mathrm{~N}_{5}\right)$ showed the disappearance of $(\mathrm{Ca} \equiv \mathrm{N})$ band due to the alkali hydrolysis of $(\mathrm{Ca} \equiv \mathrm{N})$ group to synthesis diselenide group, while the other synthesized nitrone compounds containing $(\mathrm{Ca} \equiv \mathrm{N})$ band in the region $(2101-2111)$ $\mathrm{cm}^{-1}$. Mass spectroscopy gives the molecular ion and other fragments which indicated the structure of synthesized nitrone compounds. The nitrone compounds have been diagnosed by elemental analysis, and all the results were in agreement with the theoretical. The yield of products depends on the type of substituted groups. The presence of the both electron donating and drawing groups in the nitrone compound $\left(\mathrm{N}_{3}\right)$ increases the yield of products more than the donating group as in compound $\left(\mathrm{N}_{1}\right)$ or drawing group as in compound 
$\left(\mathrm{N}_{2}\right)$. The diselane nitrone containing four donating groups as in compounds $\left(\mathrm{N}_{5}\right)$ is more yield than the diselenide nitrone containing two donating groups as in compound $\left(\mathrm{N}_{4}\right)$. Anhydrous $\mathrm{CaCl}_{2}$ was using as a drying agent to removed the water from the product and shifted the reaction to the right director.

\section{ACKNOWLEDGMENT}

I'm gratefully and thankful to Prof. Dr. Graham. J. Bodwell, college of science, University of Memorial NL-Canada for his help to complete this research in his lab.

\section{REFERENCES}

1. Al-Jassem, A. M; Majeed, N. N, J. Chemistry and Materials Research. 2014, 6, 100-108.

2. Rosselin, M.; Choteau, F.; Zeamari, K.;Nash K.M., Das, A., Lauricella R., Lojou E., Tuccio B. Villamena F.A.and Durand G., Reactivities of Substituted alpha-Phenyl-N-tert-butyl Nitrones, J. Org. Chem. 2014, 79, 6615-6626.

3. Keiko, N. A.; Funtikova, E.A.; Larina, L.I.; Sarapulova,G.I.; Mazhukin, D. G;T. V. RybalovaA, T.V.;Ya. Tikhonov, Y.A, J. Org. Chem. 2005, 41, 1421-1429.

4. Nawaz, H..; Akhter, Z.; Yameen, S. ; Siddiqi, H. M; Mirza, B.;Rifat, A, J. Organomet. Chem. 2009,694, 2198- 2203.

5. Koketsu, M. ; Kanoh, K.: Ando, H.: Ishihara, H, J. Heteroatom Chem. 2006, 17, 88.

6. Torssell K.B.G., Nitrile Oxides, Nitrones and Nitronates in Organic Synthesis, Chapter 2, Wiley-VCH, Weinheim, Germany 2008.

7. Sugie, S. ; Tanaka, T, J. Health science. 2000, 46, 422-425

8. Wirth, T.; Organoselenium Chemistry: Modern Developments in Organic Synthesis; Springer: Berlin, 2000.

9. Zink, O ; Nesvadba, P, J. Macromolecules. 2000, 33, 8106-8108.

10. Voinov, M. A. ; Grigor'ev, I. A, J. Organometallics. 2007, 26, 1607-1615.

11. Mobinikale, A ; Kalate, Z, J. Turk. chem. 2005, 29, 147.

12. Hafez, A. M.; Taggi, A. E, J. Am. Chem. Soc. 2002, 124, 6626.
13. Lipsky, B.A.; Berendt, A.R.; Deery, H.G.; Embil, J.M.; Joseph, W.S.; Karchmer, A.W.; Lefrock, J.L.;Lew, D.P.; Mader, J.T.; Norden, C. Diagnosis and treatment of diabetic foot infections. Clin.Infect. Dis. 2004, 39, 885-910.

14. Koketsu, M; Ishihara, H, J. Org. Chem. 2003, 7, 175 .

15. Torssell K.B.G., Nitrile Oxides, Nitrones and Nitronates in Organic Synthesis, Chapter 2, Wiley-VCH,Weinheim, Germany, 2008.

16. Chandrasekar, K.;.Malathi,R, J. Clin. Microbiol. 2000, 38, 3905.

17. Wang, Y.; Larrik, J , Antioxidant Nitroxides and Nitrones as Therapeutic Agents, US Patent No.6852889, February 08, 2005.

18. Sambasiva Rao, P.; C. Kurumurthy, C, J. Eur. Med. Chem. 2014, 80, 184-191.

19. Ramadan, A. A, J. Arch. Farm. Chem. Life Sci. 2006, 339, 242-249.

20. Floyd, R. A.; Kopke, R. D, J. Free Radic. Biol. Med. 2008, 45, 1361-1374.

21. Tarantelli, T.; Pecile, C, J. Org. Chem.1962, 52, 75-79

22. Michael, J. P.; Brent, R. C, J. Org. Chem., 1978, 43 (12), 2320-2323.

23. David, M. W.; Stuart,W. H, J. Org. Chem.1980, 45, 1924-1930.

24. Padungros, P, Practical Synthesis of Aromatic Dithiocarbamates. Synth Commun. 2014, 44, 2336- 2343.

25. Braslau, R.; Obryan, G, J. Synthesis. 2005, 79, 1496-1506. 